\title{
APLIKASI PROBIOTIK, IMUNOSTIMULAN, DAN MANAJEMEN KUALITAS AIR DALAM UPAYA PENINGKATAN PRODUKSI BUDIDAYA UDANG VANNAMEI (Litopenaeus vannamei) DI KECAMATAN UJUNG PANGKAH, KABUPATEN GRESIK
}

\section{Application of probiotics, immunostimulant, and water quality management to increase white shrimp (Litopenaeus vannamei) production in Ujung Pangkah Sub-District, Gresik Regency}

\author{
Nina Nurmalia Dewi ${ }^{1}{ }^{*}$, Kismiyati $^{1}$, Rozi ${ }^{1}$, Gunanti Mahasri ${ }^{1}$ dan Woro Hastuti Satyantini ${ }^{1}$ \\ ${ }^{1}$ Departemen Manajemen Kesehatan Ikan dan Budidaya Perairan, Fakultas Perikanan dan Kelautan, Universitas \\ Airlangga, Surabaya \\ *ninanurmaliadewi@fpk.unair.ac.id
}

\begin{abstract}
Abstrak
Udang vannamei merupakan salah satu komoditas perikanan budidaya yang bernilai ekonomis penting. Tingginya permintaan terhadap udang vannamei menyebabkan pentingnya kegiatan budidaya. Namun adanya berbagai permasalahan seperti penyakit dan penurunan kualitas air pada budidaya udang vannamei menyebabkan diperlukannya suatu teknologi untuk meningkatkan produksi. Tujuan kegiatan ini adalah untuk mengaplikasikan penyediaan probiotik, aplikasi imunostimulan, dan pengukuran kualitas air di tambak yang ada di Desa Pangkah Wetan dan Pangkahkulon, Kecamatan Ujung Pangkah, Kabupaten Gresik sebagai upaya untuk peningkatan produksi hasil panen tambak udang vannamei. Kegiatan ini dilaksanakan pada bulan Juli-Agustus 2019. Metode kegiatan ini adalah penyuluhan, peragaan, diskusi, dan demoplot di lapangan. Hasil kegiatan ini adalah anggota kelompok mitra berpartisipasi aktif dalam setiap tahapan kegiatan yang dilakukan. Materi yang diberikan bertujuan untuk meningkatkan pertumbuhan dan melindungi udang dari penyakit, menjaga kualitas air, dan menekan kematian udang untuk peningkatan produksi. Hasil pengukuran kualitas air dilapangan menunjukkan bahwa kondisi suhu di tambak kelompok mitra yaitu $32^{\circ} \mathrm{C}$, kecerahan $50 \mathrm{~cm}$, warna air kecoklatan, dan pH 7.
\end{abstract}

Kata kunci: Probiotik, Imunostimulan, Kualitas Air, Pertumbuhan, Produksi

\section{Abstract}

White shrimp is an economically valuable aquaculture commodity. The high demand for white shrimp causes the importance of aquaculture activities. However, there are various problems such as disease and water quality degradation in white shrimp farming, creating the need for a technology to increase production. The purpose of this work was to apply probiotics, immunostimulant, and measurement of water quality in shrimp ponds in Pangkah Wetan and Pangkahkulon villages, Ujung Pangkah Sub-District, Gresik Regency as an effort to increase the production of white shrimp ponds. This activity was conducted in July-August 2019. The method of this work was counseling, demonstration, discussion, and demonstration plots in the field. The results of this activity are members of the partner group actively participating in each stage of the activity carried out. The material provided aims to increase growth and protect shrimp from disease, maintain water quality, and reduce shrimp mortality for increased production. The results of water quality measurements showed that the temperature condition was $32^{\circ} \mathrm{C}$, transparency was $50 \mathrm{~cm}$, watercolor was brownish, and the $\mathrm{pH}$ value was 7 .

Keywords : Probiotic, Immunostimulant, Water Quality, Growth, Production

\section{PENDAHULUAN}

Indonesia merupakan negara kepulauan, negara bahari dengan 2,7 juta kilometer persegi Zona Ekonomi Eksklusif (ZEE). Hampir 75\% dari seluruh wilayah Indonesia merupakan perairan pesisir dan lautan. Terbentang di garis khatulistiwa, perairan laut nusantara menopang aneka kehidupan hayati (Dahuri, 2003). Salah satu visi untuk mendukung rencana strategis Kementerian Perikanan dan Kelautan (KKP) adalah mewujudkan Indonesia sebagai penghasil produk kelautan dan perikanan, khususnya melalui peningkatan produksi usaha budidaya (Andriyanto et al., 2014). Salah satu komoditas yang memiliki potensi dalam peningkatan usaha budidaya 
adalah tambak udang di wilayah Gresik Jawa Timur.

Udang yang berpotensi untuk kegiatan budidaya salah satunya adalah udang windu. Namun menurut Suhartini dan Farikhah (2016) pada saat ini hasil panen petani udang windu di Kabupaten Gresik mengalami penurunan karena banyak sekali udang windu yang mati sehingga hasil panen petani udang windu tidak maksimal. Oleh karena itu menurut WWF (2014), pemerintah kemudian melakukan kajian pada komoditas udang laut jenis lain yang dapat menambah produksi udang selain udang windu di Indonesia salah satunya adalah udang vannamei. Udang vannamei resmi diizinkan masuk ke Indonesia melalui SK Menteri Kelautan dan Perikanan RI. No. 41/2001, dimana produksi udang windu menurun sejak 1996 akibat serangan penyakit dan penurunan kualitas lingkungan.

Kehadiran udang vannamei di Indonesia pada awalnya dapat diterima dan berkembang dengan baik oleh para pembudidaya udang. Namun, produksi udang kembali mengalami kemerosotan beberapa tahun terakhir seiring kemunculan penyakit (Hidayani et al., 2015). Penyakit menjadi salah satu faktor pembatas dalam budidaya udang vannamei (Litopenaeus vannamei). Kegagalan budidaya udang akibat tingginya tingkat mortalitas udang budidaya diduga disebabkan oleh infeksi virus maupun bakteri patogen (Ridlo dan Pramesti, 2009 ; Nindarwi dan Yanuhar, 2013). Virus disinyalir menjadi patogen paling berperan dalam memicu penyakit pada udang. Setiap fase hidup dari udang vannamei rentan diserang oleh infeksi virus yang mengakibatkan perubahan bentuk tubuh, ukuran benih yang tidak seragam, pertumbuhan yang lambat, hingga kematian (Hidayani et al., 2015).

Oleh karena itu, perlu adanya penerapan teknologi yang dapat diterapkan pada revitalisasi tambak yang diharapkan dapat meningkatkan produksi udang. Teknologi yang diharapkan adalah teknologi yang murah, praktis, dan tepat guna.

Salah satu teknologi yang dapat diaplikasikan pada budidaya udang adalah melalui penggunaan probiotik dan immunostimulan. Menurut Lara-Flores (2011), probiotik umumnya didefinisikan sebagai mikroorganisme yang memiliki kemampuan untuk memodifikasi komposisi bakteri dalam saluran pencernaan hewan akuatik, air, dan sedimen serta dapat digunakan untuk suplemen pakan yang dapat meningkatkan kesehatan inang dan berperan sebagai agen biokontrol. Mayasari (2013) menambahkan bahwa probiotik berfungsi untuk memperbaiki kualitas air, meningkatkan respons imun dan nutrisi, dan menyingkirkan bakteri yang bersifat patogen. Selain probiotik, penerapan teknologi lain yang berperan dalam meningkatkan produksi udang adalah imunostimulan.

Imunostimulan merupakan senyawa kimia, obat atau bahan lain yang mampu meningkatkan mekanisme respons spesifik dan non spesifik ikan (Putri et al., 2013; Mastan, 2015). Peningkatan pertahanan tubuh terhadap serangan penyakit tidak hanya dapat dilakukan dengan pemberian pakan dengan komposisi nutrien yang seimbang, melainkan dapat juga disertai pemberian imunostimulan dalam pakan. Imunostimulan berhubungan langsung dengan sel sistem imun yang membuat sel tersebut lebih aktif (Ekawati et al., 2012). Oleh karena itu melalui aplikasi probiotik dan imunostimulan diharapkan dapat meningkatkan produksi udang di Kecamatan Ujung Pangkah Kabupaten Gresik.

Sampai saat ini para petambak di Desa Pangkahwetan dan Desa Pangkah Kulon Kecamatan Ujung Pangkah pengelolaan tambaknya masih menggunakan cara yang tradisional dan sederhana, sehingga hasil panen yang diharapkan masih jauh dari target yang diharapkan. Menurut Pirzan dan Utojo (2013) produktivitas tambak di wilayah 
Gresik memiliki peluang besar untuk ditingkatkan menjadi tambak semi intensif.

Upaya revitalisasi tambak di wilayah ini sudah pernah dilakukan oleh pemerintah namun produksinya masih rendah. Selain itu, karena latar belakang pendidikan masyarakat Desa Pangkahwetan dan Desa Pangkah Kulon yang masih tergolong rendah, hal ini menjadi hambatan dalam usaha budidaya udang yang selama ini masih mengandalkan cara turun temurun dari nenek moyangnya. Tujuan kegiatan ini adalah untuk mengaplikasikan penyediaan probiotik, aplikasi imunostimulan, dan pengukuran kualitas air di tambak yang ada di Desa Pangkah Wetan dan Pangkahkulon, Kecamatan Ujung Pangkah, Kabupaten Gresik sebagai upaya untuk peningkatan produksi hasil panen tambak udang vannamei. Manfaat dari kegiatan ini adalah memberikan pengetahuan kepada masyarakat mengenai peranan probiotik, imunostimulan, dan manajemen kualitas air dalam rangka peningkatan produksi udang, khususnya udang vannamei sehingga dapat meningkatkan kesejahteraan masyarakat sekitar.

\section{METODOLOGI}

\section{Waktu dan Tempat}

Penelitian ini dilaksanakan pada bulan Juli-Agustus 2019 di kelompok mitra petambak Desa Pangkah Wetan dan Desa Pangkahkulon, Kecamatan Ujung Pangkah, Kabupaten Gresik, Provinsi Jawa Timur.

\section{Materi Penelitian}

Alat yang digunakan untuk penyediaan kultur probiotik yaitu ember, selang aerasi, batu aerasi, panci, dan timbangan. Alat yang digunakan untuk aplikasi imunostimulan adalah bak, selang aerasi, batu aerasi, dan gelas ukur $10 \mathrm{ml}$. Alat yang digunakan untuk pengukuran kualitas air yaitu termometer, secchi disk, dan kertas $\mathrm{pH}$.

Bahan yang digunakan untuk penyediaan kultur probiotik diantaranya molase, susu skim, glukosa, garam, klorin, na-thiosulfat, probiotik merek Petrofish, sedangkan untuk aplikasi imunostimulan yaitu benur udang vannamei (PL-11) dan imunostimulan protein membran imunogenik Zoothamnium penaei.

\section{Rancangan Penelitian}

Berdasarkan hasil identifikasi masalah maka metode pendekatan dalam pemecahan permasalahan utama pada petambak di Desa Pangkahwetan dan Pangkah Kulon, Kecamatan Ujung Pangkah, Kabupaten Gresik yaitu sebelumnya melakukan pendekatan dengan para tokoh masyarakat khususnya para petambak. Selanjutnya pelaksanaan diuraikan menjadi tahap penyuluhan, peragaan penyediaan dan aplikasi probiotik, aplikasi imunostimulan, dan cara pengukuran kualitas air.

Masyarakat diberikan pemahaman terlebih dahulu mengenai manfaat penggunaan probiotik dan imunostimulan, dan pentingnya melakukan pemantauan kualitas air di tambak. Setelah itu dilanjutkan pada tahap kedua yaitu simulasi peragaan. Tahap selanjutnya setelah dilaksanakan penyuluhan dan simulasi peragaan, adalah demo plot atau uji coba penyediaan dan aplikasi probiotik, imunostimulan, dan cara pengukuran kualitas air di lapangan (tambak). Sehingga para petambak dapat lebih memahami cara mengaplikasikan teknologi ini untuk saat ini maupun ke depannya. Partisipasi kelompok mitra dalam kegiatan ini adalah menyediakan sarana dan prasarana selama kegiatan dilaksanakan, seperti tempat pertemuan untuk penyuluhan dan simulasi peragaan, serta tambak udang untuk demo plot aplikasi ilmu pengetahuan dan teknologi yang diberikan.

\section{Prosedur Kerja}

Uji coba aplikasi imunostimulan, probiotik, dan kualitas air dilaksanakan oleh tim dan kelompok mitra di tambak salah satu anggota kelompok mitra. Uji coba yang pertama dilakukan adalah uji coba imunostimulan pada benur udang (PL-11) yang kemudian diberikan dosis 
imunostimulan yang telah ditentukan yaitu $3 \mathrm{ml}$ per liter air dialam sebuah bak untuk benur udang vannamei 1 rean (5.000 ekor). Kemudian didiamkan selama 10 menit dengan kondisi diberikan aerasi. Setelah itu, benur udang ditebar ke tambak.

Selanjutnya adalah uji coba penyediaan kultur probiotik dengan menggunakan alat dan bahan yang telah disediakan dan dosis yang telah ditentukan. Setelah uji coba pembuatan kultur probiotik, dilanjutkan dengan pengukuran kualitas air di tambak seperti suhu dengan menggunakan termometer, kecerahan dengan menggunakan secchi disk, dan $\mathrm{pH}$ dengan menggunakan kertas $\mathrm{pH}$. Untuk pengamatan warna air dilakukan secara langsung.

\section{Analisis Data}

Analisa data yang digunakan adalah analisis deskriptif.

\section{HASIL DAN PEMBAHASAN}

Pelaksanaan pengabdian masyarakat tahap pertama dilaksanakan pada bulan Juli 2019. Hasil penelitian ini adalah anggota kelompok mitra yaitu kelompok petambak udang Desa Pangkahwetan dan Pangkah Kulon sangat bersemangat dan antusias dalam kegiatan ini. Materi penyuluhan yang disampaikan adalah mengenai penyediaan kultur probiotik dalam mendukung produksi udang di Kecamatan Ujung Pangkah Gresik dan aplikasinya di lapangan.

Menurut Gunarto et al. (2016) probiotik berperan dalam memperbaiki kualitas air, bahan organik total, amonia maupun fosfat. Selain itu penambahan probiotik pada wadah pemeliharaan udang juga berfungsi sebagai komplemen sumber pakan atau berkontribusi pada sistem pencernaan udang dan dapat menekan bakteri patogen karena bakteri probiotik mampu menghasilkan bahan anti bakteri seperti bakteriosin, lisozim, protease, siderofor, hidrogen peroksida ataupun asam organik.
Menurut Wang et al. (2017) imunostimulan berperan dalam mengaktifkan sistem kekebalan hewan akuatik dan meningkatkan ketahanan tubuh terhadap penyakit. Dalam hal ini imunostimulan yang digunakan adalah imunostimulan protein membran imunogenik Zoothamnium penaei yang sudah diteliti oleh Mahasri (2007) dimana berdasarkan hasil penelitian, menunjukkan bahwa penggunaan imunostimulan tersebut dapat meningkatkan kelangsungan hidup udang windu dari 10\% hingga mencapai 96\%. Penelitian Hidayat et al. (2017), menambahkan bahwa pemberian pakan yang ditambahkan crude protein Zoothamnium penaei mampu meningkatkan kelulushidupan udang vannamei dari $21 \%$ hingga $72 \%$ selama 90 hari pemeliharaan di tambak.

Kualitas air memainkan peran penting dalam meningkatkan produktivitas tambak udang. Kualitas air yang baik memberikan nutrisi seimbang dan lingkungan yang sehat untuk hewan budidaya. Oleh karena itu manajemen kualitas air sangat penting dalam budidaya. Faktor fisika-kimia air seperti suhu, kecerahan, salinitas, oksigen dan lain-lain mempengaruhi kualitas air baik secara langsung maupun tidak langsung, yang pada akhirnya mengatur kelangsungan hidup organisme di ekosistem perairan (Rahman et al., 2015).

Kualitas air yang diukur meliputi suhu, kecerahan, warna, dan $\mathrm{pH}$. Berdasarkan hasil pengukuran, nilai suhu dan $\mathrm{pH}$ masih berada pada batas optimal atau batas toleransi. Namun untuk warna, tambak tersebut berwarna kecokelatan sedangkan yang optimal untuk budidaya udang vannamei adalah hijau kecokelatan. Untuk nilai kecerahan berada pada kisaran yang tidak optimal yaitu $50 \mathrm{~cm}$, sedangkan batas kecerahan yang optimal untuk udang vannamei yaitu pada kisaran $25-40 \mathrm{~cm}$ (Tabel 1). Hal ini mengindikasikan bahwa tambak tersebut masih tergolong jernih karena memiliki kandungan plankton yang sedikit. 
Menurut Mahmud et al. (2012) plankton khususnya fitoplankton sangat penting untuk pengembangan budidaya tambak, dimana salah satu faktor yang berperan penting dalam pertumbuhan fitoplankton adalah nutrien. Selain berasal dari sungai, suplai nutrien di tambak biasanya berasal dari pemupukan. Hal ini dikarenakan pemupukan memiliki dampak yang cukup besar terhadap peningkatan biomassa fitoplankton.

Tabel 1. Kualitas air di salah satu tambak kelompok mitra.

\begin{tabular}{lll}
\hline Parameter & Hasil & Literatur (WWF, 2014) \\
\hline Warna & Kecokelatan & Hijau kecokelatan \\
Suhu ${ }^{\circ} \mathrm{C}$ & 32 & $28-32$ \\
Kecerahan $(\mathrm{cm})$ & 50 & $25-40$ \\
pH & 7 & $7-8,5$ \\
\hline
\end{tabular}

\section{KESIMPULAN DAN SARAN Kesimpulan}

Kelompok mitra petambak udang Desa Pangkah Wetan dan Pangkahkulon sangat antusias dalam mengikuti kegiatan ini. Kegiatan yang sudah dilakukan yaitu meliputi penyuluhan, simulasi peragaan, dan demo plot terkait penyediaan dan aplikasi probiotik pada budidaya udang, imunostimulan, dan pengukuran kualitas air. Hasil pengukuran kualitas air tambak kelompok mitra memiliki suhu dan $\mathrm{pH}$ yang optimal, namun untuk warna dan kecerahan masih belum optimal, sehingga bisa dilakukan pemupukan yang bertujuan untuk meningkatkan kelimpahan plankton khususnya fitoplankton sebagai sumber pakan alami udang. Melalui kegiatan pengabdian masyarakat ini diharapkan dapat meningkatkan pengetahuan dan pemahaman para petambak udang dengan tujuan untuk meningkatkan hasil panen udang vannamei.

\section{Saran}

Perlu dilakukan monitoring aplikasi probiotik, imunostimulan, dan pengukuran kualitas air di tambak secara berkala sampai panen, sehingga dapat diketahui pengaruhnya terhadap pertumbuhan dan kelangsungan hidup udang vannamei di Kecamatan Ujung Pangkah, Gresik.

\section{DAFTAR PUSTAKA}

Andriyanto, F., Efani, A. dan Riniwati, H., 2014. Analisis Faktor-Faktor
Produksi Usaha Pembesaran Udang Vanname (Litopenaeus Vannamei) di Kecamatan Paciran Kabupaten Lamongan Jawa Timur; Pendekatan Fungsi Cobb-Douglass. ECSOFiM (Economic and Social of Fisheries and Marine), 1(1), pp.82-96.

Dahuri, R., 2003. Keanekaragaman hayati laut: aset pembangunan berkelanjutan Indonesia. Gramedia Pustaka Utama.

Ekawati, A.W., Nursyam, H., Widjayanto, E. dan Marsoedi, M., 2012. Diatomae Chaetoceros ceratosporum dalam Formula Pakan Meningkatkan Respon Imun Seluler Udang Windu (Penaeus monodon Fab.). The Journal of Experimental Life Science, 2(1), pp.20-28.

Gunarto, G., Mansyur, A. dan Muliani, M., 2016. Aplikasi Dosis Fermentasi Probiotik Berbeda Pada Budidaya Udang Vaname (Litopenaeus vannamei) Pola Intensif. Jurnal Riset Akuakultur, 4(2), pp.241-255.

Hidayani, A.A., Malina, A.C., Tampangallo, B.R. dan Fathurrahman, A.F., 2015. Deteksi Distribusi White Spot Syndrome Virus pada Berbagai Organ Udang Vaname (Litopenaeus Vannamei). Torani (Jurnal Ilmu Kelautan dan Perikanan), 25(1), pp. 1-6.

Hidayat, R.P., Suwarno, dan Mahasri, G., 2017. Evaluasi Pemberian Crude Protein Zoothamnium penaei 
Terhadap Laju Pertumbuhan, Respon Imun dan Kelulushidupan Udang Vaname (Litopenaeus vannamei) Di Tambak. Jurnal

Biosains Pascasarjana, 19(2).

Lara-Flores, M., 2011. The use of probiotic in aquaculture: an overview. International Research Journal of Microbiology, 2(12), pp.471-478.

Mahasri, G., 2007. Protein Membran Imunogenik Zoothamnium penaei Sebagai Bahan Pengembangan Imunostimulan Pada Udang Windu (Penaeus monodon Fabricus) Terhadap Zoothamniosis. Disertasi. Surabaya: Universitas Airlangga.

Mahmud, S., Aunurohim, A. dan Tjahyaningrum, I.T.D., 2012. Struktur Komunitas Fitoplankton pada Tambak dengan Pupuk dan Tambak Tanpa Pupuk di Kelurahan Wonorejo, Surabaya, Jawa Timur. Jurnal Sains dan Seni ITS, 1(1), pp.E10-E15.

Mastan, S.A., 2015. Use of immunostimulants in aquaculture disease management. International Journal of Fisheries and Aquatic Studies, 2(4), pp.277-280.

Mayasari, E. 2013. Pengaruh pemberian bakteri asam laktat terhadap kelangsungan hidup ikan kerapu macan (Epinephelus fuscoguttatus). Skripsi. Fakultas Perikanan Dan Ilmu Kelautan Universitas Riau.

Nindarwi, D.D. dan Yanuhar, U., 2013. Non-Specific Immune Response of Vanname Shrimp (Litopeaneus vanname) Induced by Chitosan as an Immunomodulator against IMNV (Infectious Myonecrosis Virus) Exposure. Journal of Biology and Life Sciences, 4(2), pp.320-327.

Pirzan, A.M. dan Utojo, U., 2013. Pengaruh Variabel Kualitas Air terhadap Produktivitas Udang Vaname (Litopenaeus vannamei) di Kawasan Pertambakan Kabupaten Gresik, Jawa Timur. Majalah Ilmiah Biologi
BIOSFERA: A Scientific Journal, 30(3), pp.1-8

Putri, F. M., Sarjito, dan Suminto., 2013. Pengaruh Penambahan Spirulinasp. dalam Pakan Buatan Terhadap Jumlah Total Hemosit dan Aktivitas Fagositosis Udang Vaname (Litopenaeus vannamei). Journal of Aquaculture Management and Technology, 2(1), pp. 102-112.

Rahman, M.Z., Zaman, M.F.U., Khondoker, S., Hasan-Uj-Jaman, M., Hossain, M.L. dan Bappa, S.B., 2015. Water quality assessment of a shrimp farm: A study in a salinity prone area of Bangladesh. International Journal of Fisheries and Aquatic Studies, 2(5), pp.09-19.

Ridlo, A. dan Pramesti, R., 2009. Aplikasi ekstrak rumput laut sebagai agen imunostimulan sistem pertahanan non spesifik pada udang (Litopennaeus vannamei). ILMU KELAUTAN: Indonesian Journal of Marine Sciences, 14(3), pp.133-137.

Suhartini, dan Farikhah, 2016. IbM Petani Udang Windu Duduksampeyan Gresik Jawa Timur. Prosiding Seminar Nasional Ekonomi dan Bisnis \& Call For Paper FEB UMSIDA 2016.

Wang, W., Sun, J., Liu, C. dan Xue, Z., 2017. Application of immunostimulants in aquaculture: current knowledge and future perspectives. Aquaculture Research, 48(1), pp.1-23.

World Wide Fund for Nature (WWF), 2014. Better Management Practices Budidaya Udang vannamei. WWF Indonesia. 